\title{
It Takes a Village: Advancing Attachment Theory and Recovering the Roots of Human Health with the Circle of Seven Essential Needs
}

\author{
Mike Sosteric \\ https://athabascau.academia.edu/DrS
}

Gina Ratkovic

Version 1.00

\begin{abstract}
Bowlby's Attachment Theory (AT) remains a popular way to understand infant, child, adolescent, and even adult and family dysfunction. However, attachment theory, which has not changed significantly since its inception, is a reductive theory that ignores a wider range of human needs and has caused significant hardship and trauma. The limitations of this model, particularly when applied outside the Eurocentric and ethnocentric frames of mainstream psychology, are well known. In this article, we suggest it is time to replace the reductive theory of needs that underpins AT with a comprehensive theory, one that could help us develop a less ideological, healthier, and more empirically informed approach to socialization and social care; one that might help us answer Abraham Maslow's Eupsychian question which is how to build a society capable of actuating the full potential of all its citizens.
\end{abstract}

Keywords: Abraham Maslow, John Bowlby, Attachment Theory, Hierarchy of Needs, Circle of Seven Essential Needs, Eupsychian Psychology 
As soon as you're born they make you feel small

By giving you no time instead of it all 'Til the pain is so big you feel nothing at all

They hurt you at home and they hit you at school They hate you if you're clever and they despise a fool 'Til you're so fucking crazy you can't follow their rules

When they've tortured and scared you for 20 odd years Then they expect you to pick a career When you can't really function, you're so full of fear Keep you doped with religion, and sex, and T.V. And you think you're so clever and classless and free But you're still fucking peasants as far as I can see

\author{
John Lennon, Working Class Hero
}


In Western colonial psychology, Attachment Theory (AT) remains a respected and profoundly influential way to understand infant, childhood, adolescent, and even adult attachment behaviour (Mercer, 2011). Despite criticism, attachment to attachment theory has not declined but has, with the birth of the Internet, intensified (Rosabal-Coto et al., 2017), with "more articles being published on the subject in the last 5 years than the preceding 25 years combined" (Yip et al., 2018, p. 185).

Attachment Theory itself derives from Bowlby's research on delinquent children (Bowlby, 1944) and his work with the World Health Organization on institutionalized children in post-war Europe, both of which presented to him the reality that children in institutions or foster homes suffered serious cognitive and emotional impairment (Bowlby, 1966). Bowlby theorized the impairments were caused by maternal deprivation, or the absence of a loving and nurturing mother or "permanent mother-substitute," the so-called monotropic model (Voges et al., 2019). In his seminal research study, Bowlby asserted that separation from, and lack of attachment to, the primary female caregiver was an essential determinant of future mental health (Bowlby, 1966, p. 11).

Why did Bowlby focus on the mom and not something else, like under staffing of an institution, physical confinement, or institutional violence, all of which are common experiences in institutional settings. Because, according to Bowlby, infants and young children were biologically primed to attach to mothers and this attachment itself was critical for long-term health. Why the moms and not the dads? Initially, psychologists theorized this was because mothers met the infant's physiological needs (Bowlby, 1982), but after Harlow's experiments, demonstrated that cuddle time or "contact comfort" was important, Bowlby suggested infants have a biologically rooted instinct to attach to the mom because they need protection from predators, because without that secure protection they would not be able to safely explore the world around them. This need for protection resulted, according to Bowlby, in the evolutionary development of an attachment behavioural system that motivates all living organisms to attach to their mothers (Bowlby, 1982). 
Given the persistence and consistent respect afforded to his theory of attachment, one would think it quite special. However, even a quick perusal of Bowlby's book (1982) finds a purposely reductive perspective narrowly focused on safety and security needs and the attached mother's ability to meet these needs as the key driver of psychological and emotional health and pathology. Bowlby himself originally considered pathogenic outcomes may be driven by other factors and needs, like parental conflict, mixed emotional messaging, "an excessive demand for love and reassurance on the part of a parent," (Bowlby, 1966, p. 13), and even the need to learn (Bowlby, 1982, p. 223). He was also clearly aware of institutional drivers of physical, cognitive, and emotional disease, like under staffing, physical confinement, institutional violence, and maltreatment (Follan M \& Minnis H, 2010). Finally, he was aware of socioeconomic factors, like poverty, even going so far as to recommend dramatic increases in financial, medical, psychological, emotional, and daily supports (Bowlby, 1966) to facilitate better individual and family outcomes; however, he ultimately rejects an expanded conceptualization of attachment and psychological pathology and reduces an otherwise complicated developmental situation in two ways. One, he reduces the causes and functions of attachment to the single biological need for safety and security. Two, he reduces the satisfaction of that need to the responsibility of a single, female caregiver.

Why does Bowlby reduce a complicated situation in this fashion? We can think of a few reasons. Number one, Bowlby was a scientist and among scientists there is an overtly stated preference for parsimonious theories - the application of Occam's Razor-because better theories are always simpler theories (Everett J. Nelson, 1936; Lewis White Beck, 1943). This principle likely motivated Bowlby to find the simplest explanation for the pathology he observed. Number two, Bowlby was heavily influenced by the Darwinian zeitgeist, citing him throughout his book Attachment Theory. His understanding of Darwinian theory suggested he reduce human behaviour to simple selection pressures. As he stated in his book, he wanted to find the "essential advantage" (Bowlby, 1982, p. 226) that led to the natural selection of attachment behaviour. For Bowlby, that was the protection from predators that moms provided. Infants and children that attached and did not wander off into the wilderness would be more likely to survive, which would naturally select children with propensity to attach. This was the 
essential evolutionary advantage that drove the evolutionary development of Bowlby's "attachment behaviour system." A third reason for the reduction may have been ideological, a factor that has recently come to the attention of psychological theorists attempting to extricate themselves and their discipline from the suppressive influence of Eurocentric thinking and Neoliberal ideology (Carr \& Batlle, 2015). Essentially, Bowlby and others present a theory of human development and human pathology, a sexist model of child development, that is patriarchal and Eurocentric and that elevates a Capitalist model of socialization that pushes responsibility for childcare into the lonely lap of the isolated, unpaid homemaker because this allows for the cheap reproduction of the labour force (Gorz, 1999). Attachment theory, born from the loins of Eurocentric and patriarchal scientists, conveniently provides "scientific" justification for neoliberal policies that minimize the necessity and cost of state supports (Rippeyoung, 2013).

Parsimony, Darwinian reductionism, and Capitalist/Eurocentric bias may explain the double theoretical reduction; whatever the reasons, however, a key question is, is the doubly reductive nature of attachment theory a problem? The answer depends on the empirical sufficiency of the theory, whether or not the reductive focus has been harmful, and whether the popularity of the theory has limited our understanding of attachment and human development. If the theory does not reflect the actual complexity of reality, if it has caused harm in any way, and if it has undermined better theorization, then the reductive theory is a problem.

It is possible to question the empirical sufficiency of the theory. As already noted, even a cursory reading of Bowlby's seminal work provides evidence against reducing human pathology down to an attachment failure. That is, Bowlby himself reports many contributing factors, like institutional violence, under staffing, poverty, parental psychopathology, and more, all of which make the reduction of human pathology to maternal attachment highly suspect. Beyond Bolwy, awareness of the reductive, normative, Eurocentric, and colonial functions of AT have led to calls for rethinking (Carr \& Batlle, 2015; McCarthy \& Gillies, 2018; Neckoway et al., 2007). More recent theorists have rejected monotropic assumptions and acknowledged that children attach to more than just their mothers" (Rutter, 1995, p. 551) and for more than just reasons of security. They attach to fathers when they are around, friends early on, organizations, priests, gurus, and 
workplaces as well. They attach to mothers and others because mothers and others meet other of their needs, like the need for love or the need for truth or the need for esteem. Researchers have also pointed out attachment requirements extend beyond infancy and early childhood into a second "sensitive period" in adolescence where adolescents require "attachment security" as much as, or more, than infants and young children (Cassidy et al., 2013).

In addition to its obvious empirical insufficiency, the double reduction has indeed caused harm. Underlying gender stereotypes support an unequal division of labour in the home that privileges the male and requires a double-day from females. Notions that children are primed to attach to mothers, and that mothers are primarily responsible for mental and emotional health, help downplay the importance of costly community and state supports. Placing primary responsibility on an isolated female leads to negative mental and physical consequences for women, particularly single-parents (Sharon Hays, 1998), who end up bearing the lion's share of a family's emotional labour (Strazdins \& Broom, 2004), and who must also deal with the "inevitable accompaniment of maternal guilt" (Rosabal-Coto et al., 2017, p. 337) that accrues when they cannot complete the otherwise impossible task of raising a healthy child on their own. AT has also imposed serious disadvantages on Indigenous families, particularly through the child and family intervention systems (Choate et al., 2020) where "disorganized attachment" has been used as a marker of abusive parenting and as justification for child intervention and removal (White et al., 2019). It is also possible that the reductive focus has harmed children directly. Infants and children have many needs, not just a need for security. Reducing the constellation of needs to a single need provided by a single agent not only directs research attention but parental attention as well. Parents, and indeed an entire society, fixated on Bowlby's single need may very well end up undermining full child development.

Finally, Bowlby's reductive theorization may have also blocked critical awareness of the deficiencies of the Capitalist model of socialization and it may have stymied more sophisticated and critical theorization. The Eurocentric and ideologically rooted presumptions that extant Capitalist socialization processes, processes that foreground gender, a gendered division of labour, individuality, self-sufficiency, independence, and early detachment from parents and 
family (which of course benefits consumer Capitalism by forcing the creation of independent consumer pods, effectively doubling consumer demand), are necessarily an advance over earlier more collectively oriented systems means AT researchers have only recently begun to ask critical questions of the dominant European systems of socialization, systems which, as critical theorists have long pointed (Fanon, 1963), are incredibly toxic, having more to do with ideology and the imposition of Capitalist friendly socialization (read worker training) practices and relational styles (Anyon, 1980; McCarthy \& Gillies, 2018) conducive to worker exploitation and consumer accumulation than they are about health, well being, and the actualization of full human potential. The key point is, Capitalist socialization practices, which Attachment Theorists implicitly elevate, are arguably toxic. We can see the toxicity of the colonial socialization system clearly when we look at residential schools, which remove children and places them in violent institutional settings so that they can be trained and assimilated as worker bees; however, we do not see the toxicity when we look at the standard European practices, which also remove children from the home at an early age and place them in violent and underfunded institutional settings designed to prepare them for a place in the workforce via indoctrination and assimilation. When, dysfunction, disease, and failed actualization results, rather than looking at the colonial socialization process in general, we lay the blame on moms and their children.

Despite the questionable reductionist perspective initiated by Bowlby, there can be no doubt that attachment is an important thing, and that it is cross-culturally significant. The question is though, how to properly understand attachment? We suggest a simple way forward is to reduce the double reduction. Steps have been taken in this direction. The rejection of a monotropic view of attachment has opened awareness that we attach to more than just the mother. Research has demonstrated that we attach to other significant figures, groups (Murphy \& Coats, 1999) and organizations (Frazier et al., 2015; Hazan \& Shaver, 1990; Yip et al., 2018). While a step in the right direction, these attempts are insufficient. Not only have they failed to push back the conservative monotropic narrative (Rippeyoung, 2013), but the theory retains its reductive focus on a single biological root of attachment (Kammrath \& Clifton, 2018; Schore \& Schore, 1994). As one scholar notes, "Bowlby's attachment theory, one of the last of the 'grand theories,' has 
not been replaced or extensively reworked." (Mercer, 2011, p. 42). Rejecting the monotropic model is not enough. Clearly, more is needed.

\section{Expanding the Base-The Seven Essential Needs}

One possibly fruitful way forward is to extend the biological basis for attachment beyond Bowlby's reductionist emphasis on the single need for safety and security to other established human needs. We suggest, therefore, The Circle of Seven Essential Needs as the model from which to understand not only the significance and dynamics of attachment, but also the key parameters of human health and development. The Circle of Seven Essential Needs is illustrated in the figure below. 


\section{SEVEN ESSENTIAL NEEDS}

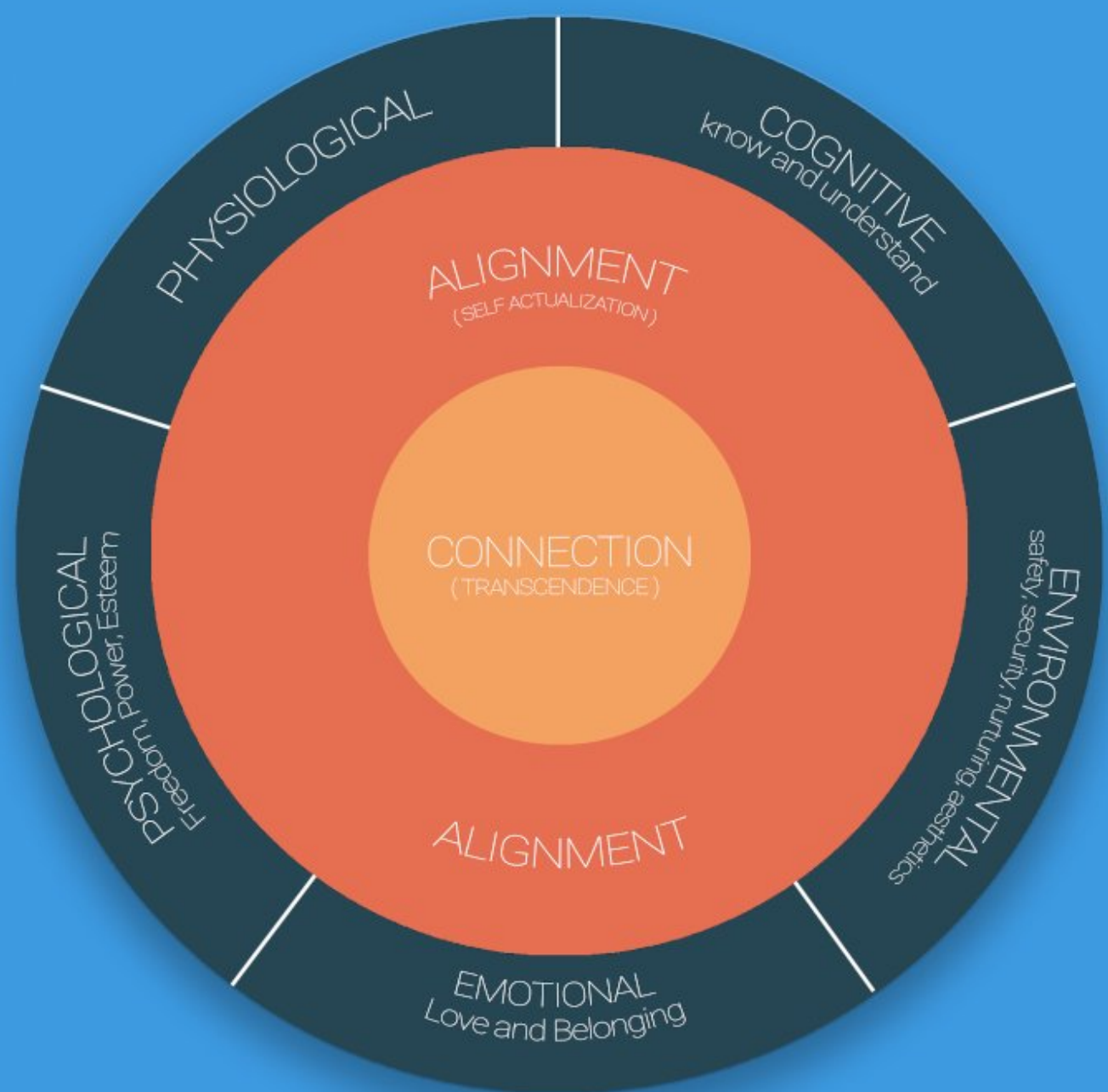


The Circle of Seven Essential needs represents the sum total of all needs that humans must meet if they are to grow up healthy and strong. The circle itself is organized into three concentric circles, an outer circle of basic needs and two inner circles, one representing our need for alignment and the other representing our need for connection.

The Circle of Seven Essential Needs is inspired by Abraham Maslow's career-spanning efforts to provide a comprehensive list of human needs. His attempt began in 1943 with the publication of two seminal articles (Maslow, 1943a, 1943b) wherein he identified two hierarchies of needs, a hierarchy of basic needs which included physiological, safety, love/belonging, esteem, and self-actualization needs, and a second "small hierarchy" of cognitive needs (Maslow, 1943a, p. 385), which included our biologically rooted needs to know "the facts" and understand how it all works together (Maslow, 1943a, p. 385). Maslow's theory was not static. As his work progressed, he expanded his original conceptualization of basic and cognitive needs to include aesthetic needs (Maslow, 1954), the needs for creative outlets (Hoffman, 1999), and the need for "transcendence,"which he set as the highest need. As he says in his notebook on Eupsychian management, "We must ultimately assume at the highest theoretical levels of eupsychian theory, a preference or a tendency to identify with more and more of the world, moving toward the ultimate of mysticism, a fusion with the world, or peak experience, cosmic consciousness, and so on" (Maslow, 1965, p. 33: emphasis added).

By the end of his career Maslow's theory had evolved to be quite comprehensive. So why not just use his conceptualizations or his iconic pyramid of needs to expand AT? Why a novel presentation? For several reasons. For one, his theory of needs is disjointed and scattered. He added to his theory throughout his career but was not able to provide an updated systematization and refinement before his premature death. A second reason is that Maslow's original conceptualization of needs as a hierarchy of prepotency has been criticized for being internally inconsistent (Bouzenita \& Boulanouar, 2016), empirically weak (Soper et al., 1995), ethnocentric (Townsend \& Wrathall, 1997), sexist (Nicholson, 2001), and neoliberal, encouraging us to focus "more on personal growth than on social reform" (Aron, 1977, p. 13). Some have suggested, quite correctly, that the characterization of human needs in a hierarchy with "self" actualization 
at the top of a pyramid reflects a form of western cultural and scientific hegemony (Bouzenita \& Boulanouar, 2016) that privileges "individuality" and "individual improvement" over more family-oriented, socially embedded, collectivist needs and values (Kuo-Shu Yang, 2003). A third reason we provide a novel presentation is that to this day, Maslow's thinking is misrepresented in the psychological corpus. Psychologists have ignored his second pyramid of cognitive needs, ${ }^{1}$ his addition of aesthetic needs, and his statements about the significance and importance of transcendence. Textbooks continue to present his theory with the iconic pyramid of needs, a pyramid which is not only a stale snapshot of his 1943 statements, but is in fact, and this is the fourth and final reason we need a new presentation, an ideologically rooted misrepresentation. Maslow never represented his theory as a pyramid, or in any geometric form (Bridgman et al., 2019) for that matter. The closest Maslow came to suggesting a geometric symbol was his use of a metaphor of nested boxes to caution against a simple listing of needs (Maslow, 1943b). In actual fact, the pyramid, represented below, is a co-optation and Capitalist friendly framing of Maslow's theory provided by a management consultant concerned to find a way to use Maslow's theory to inform more efficient and cost-effective methods to manipulate workers. The hierarchy appeared for the first time ever in a management periodical (McDermid, 1960) where it replaced alternative geometrical representations, like steps (Davis, 1957) and ladders (Wren, 1972), being discussed at the time. ${ }^{2}$

1 Why has psychology ignored Maslow's second important hierarchy? It could be a simple oversight, but if it is, it points to a painful lack of rigour when dealing with Maslow's work. Another possibility is unconscious bias. The reality is, people are not told the truth about the Capitalist system, its imperialist underpinnings, its exploitation of workers, elite manipulation of government, and so on. Perhaps insisting that children be told the truth of things so they can fully understand the world, things antithetical to the functioning of patriarchy, Capitalism, brings an uncomfortable, unconscious challenge, and so they overlook this second hierarchy.

2 Management theorists Bridgman et al. (2019) recognize the intractable problems with the pyramid. They suggest the way forward is to use a ladder as the visual icon instead. Despite their suggestion that this better reflects the progressive potentials and intent of Maslow, a ladder in fact, and obviously, retains the heavily criticized hierarchical, individualistic, elitist, neoliberal, capitalist, and prepotent components of the theory, components ironically illustrated by the ladder image presented on page 86 of their article, an image which, remarkably, shows an imperialist male in a business suit planting an American flag at the top of a long, individualistic, and we can assume corporate, climb. 


\section{Management's Hierarchy of Needs}

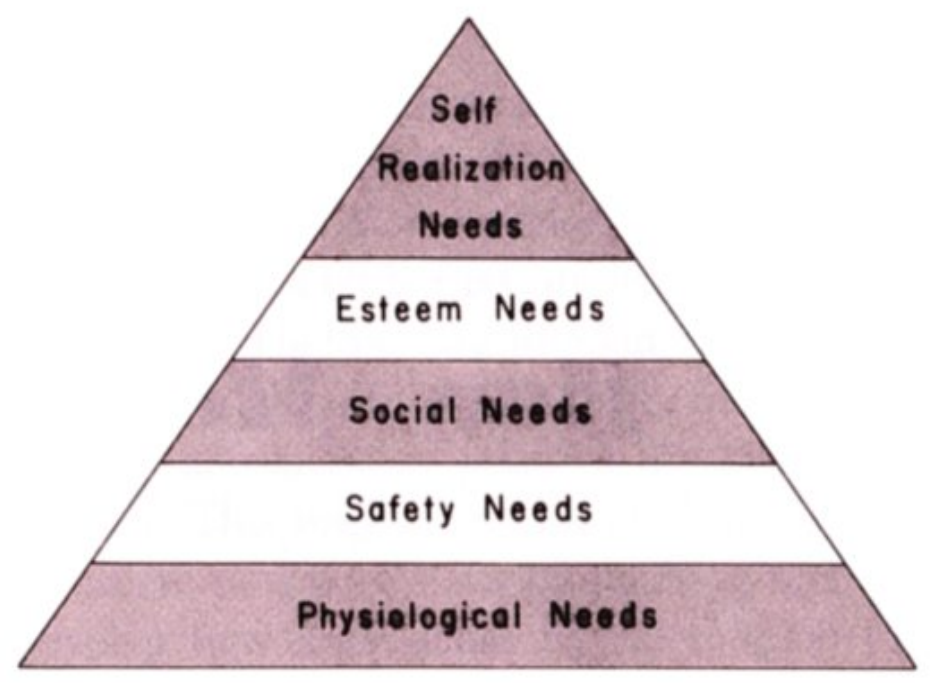

McDermid's Hierarchy of Needs (McDermid, 1960)

All the above may provide a justification and motivation for coming up with a new representation, but the question then becomes, why a circle? Not only because Ratkovic, a member of the Nakota First Nation in Saskatchewan, insisted upon a rework rooted in a more Indigenous circular view, but also because (as therapists, animal lovers, and parents) this is what we have observed. It is also what Maslow himself was suggesting nearer the end of his life (Maslow, 1968, p. 33) and, finally, it better represents the empirical reality, pointed to by many critics, that needs are not prepotent, that they are satisfied in parallel, and they are not organized into a hierarchy. If one wants their child to develop self actualize (align) and transcend (connect), for example, their basic needs must be met consistently and sufficiently for extended periods.

\section{The Circle of Seven Essential Needs - The Basic Needs}

As illustrated in the illustration of Seven Essential Needs above, the outer circle of basic needs includes five categories of basic needs. These categories, which include the physiological, cognitive, emotional, psychological, and environmental needs, are based largely on a systematization of statements spread throughout Maslow's corpus. Our own additions are noted. 
1. Physiological Needs - Physiological needs include the need for substances (like food, water, vitamins, air), the need for physical activity (exercise), and so on. Meeting physiological needs keeps the body healthy and growing and is the basis for realization of full physical and neurological potential.

2. Environmental Needs - Maslow's original theorization included a category of needs which he called safety needs, meaning essentially safe environment. For reasons of theoretical clarity and as a pathway for including Maslow's later statements, we reconceptualize safety needs as environmental needs and include not only Maslow's original need for a safe environment, basically the foundation for Bowlby's original AT, but also Maslow's later suggestion that we need aesthetically pleasing environments at home, work, and everywhere (Maslow, 1954). Environments that are safe, nurturing, secure, calm, and aesthetically pleasing encourage, according to Maslow (Maslow, 1967, p. 197), "free, uninhibited, uncontrolled, trusting, unpremeditated expression of the self" and the expression of "pure spontaneity." Note, we understand a safe environment to be an environment free from all forms of psychological, emotional, physical, spiritual violence and chaos. We go further than this however and stipulate children, adolescents, and adults also need a stable (including psychological, emotional, and parental stability) and secure (meaning a level of financial security that removes anxiety about work and survival) environment.

3. Cognitive Needs - The category of cognitive needs as proposed by Maslow include our biologically rooted need to know and understand the world, to know the facts and to theorize those facts (Maslow, 1943a).

4. Emotional Needs - Maslow's original conceptualization included a category of "love needs." These needs include our "love and affection and belongingness" needs (Maslow, 1943a, p. 380). In order to provide a container capable of expansion, we reconceptualize these needs more generally as emotional needs and include the needs for support, acceptance, and inclusion in family, friend groups, and society. Maslow 
indicated these needs are no less important for physical health and well-being than physiological needs. As he said, "No psychological health is possible unless this essential core of the person is fundamentally accepted, loved and respected by others and by himself" (Maslow, 1968, p. 196).

5. Psychological Needs - Maslow's original theory included a category for esteem needs. According to Maslow, esteem needs contain two subsidiary sets of needs, "first, the desire for strength, for achievement, for adequacy, for confidence in the face of the world, and for independence and freedom. Secondly...the desire for reputation or prestige... recognition, attention, importance or appreciation" (Maslow, 1943a, pp. 381-382). We reconceptualize these esteem needs as psychological needs and include in this expanded category the need for power and the need for freedom. Freedom were clearly on Maslow's radar. As he suggests, "Such conditions as freedom to speak, freedom to do what one wishes so long as no harm is done to others, freedom to express oneself, freedom to investigate and seek for information, freedom to defend oneself, justice, fairness, honesty, orderliness in the group are examples of such preconditions for basic need satisfactions" (Maslow, 1970, p. 47). Since freedom to do things requires power to do things, we include the need for power. As Maslow said, power is "the feeling of having some control over fate, of not being a helpless tool, a passive object, a cork on the wave which is tossed here and there by forces out of control" (Maslow, 1961, p. 2). In order to be in a healthy psychological space, we need to feel confident in our abilities, have solid self esteem, and have the power and freedom to grow and learn in line with our own needs and any community predilections.

To be clear, insufficient and inconsistent satisfaction of basic needs will lead to psychological, emotional, and physical atrophy as well as various forms of psychopathology, while sufficient satisfaction of the basic needs will provide the foundation for not only health and well being, but also for satisfaction of the inner needs. Children are biologically programmed to attach to those who help meet their needs. 


\section{The Inner Needs}

Moving on to the inner needs, the first is the need for alignment. Alignment here refers to inner alignment and outer alignment. Inner alignment refers to cognitive, emotional, and behavioural alignment with one's inner Self. If one has natural capacity as a musician, one aligns with that inner musician by thinking, acting, and behaving like a musician. Note that inner alignment is a functionally equivalent reformulation of Maslow's need for self-actualization, which originally meant aligning with and "actualizing" one's "essential biologically based inner nature" (Maslow, 1968, p. 3). Although we feel self-actualization does, in fact, reflect a real process of actualizing one's essential inner nature, alignment is a superior term because it is, as we shall see below, culturally neutral, whereas Maslow's term self-actualization, which elevates and privileges a Eurocentric, colonial, Capitalist friendly concept of individuality and individual development, is not, despite his claims (Maslow, 1968, p. vi).

The primary benefit of reconceptualizing actualization to alignment lies in its ability to lead us in the direction of less sexist, less Eurocentric, less colonial, less individualist ways of conceiving of human development and human attachment. In line with this, in addition to inner alignment or "self-actualization" we also propose a need for external alignment, which is our evolutionary programmed and biologically rooted need to align with family, community, traditions, ancestors, and so on. Outer alignment means essentially fitting in and expressing the norms, values, and beliefs of family, groups, community, etc.. When we are aligned with our family, for example, we participate in family traditions, represent family values, and provide support for family members. Note, this need for outer alignment drives our oft-observed and essential social nature and empirically observable attachment to groups and organizations, something which organizations like Google and others are more than willing to exploit in their efforts to build a super-productive "herd" of employees (Akorede, 2018; Frazier et al., 2015).

The final inner need, the need at the centre of the circle, is the need for connection to something more than one's individualized, atomized, self. This need for connection is a reformulation of Maslow's need for transcendence, which he added to the top of his hierarchy of needs (Koltko-Rivera, 2006) after observing the prevalence of peak and mystical experiences in 
the general population (Sosteric, 2018a). We rename the need for transcendence to connection not only because there is considerable confusion surrounding the meaning of the term (Maslow, 1969), but also because transcendence itself is better understood as a step on the road to better connection and not the actual endpoint. Maslow himself suggested this when he said that one transcends ideology, "enculturation," "deficits," psychological trauma, the ego (Maslow, 1968, p. 37), emotional blockage, and so on, in order to heal, strengthen and establish connection with something more than the atomistic ego. When "the distinction between self and not-self has broken down (or has been transcended) [there is now] less differentiation between the world and the person because he has incorporated into himself part of the world...His self has enlarged enough to include his child. Hurt his child and you hurt him....[he has fused] with the non-self.. [which includes]...not only...the world of nature...[but] other humans beings...[to the point that]...'selves overlap" (Maslow, 1967, p. 103). Clearly, Maslow is speaking of connection to something more than the atomized, individual, "actualized" self. Note, Maslow's conception here is more in line and sympathetic with traditional cultures, shamanic practices, Catholic mysticism, Aboriginal dream times (Lawlor, 1991), and research on modern mystical experiences, all of which indicate the significance and importance of transcendence/connection not only to other human beings and human groupings, but to nature, the cosmos, but even to divine union with "God" (Ernst, 1997; Kalisch, 2006; St. Teresa of Avila, 2007; Steeman, 1975; Underhill, 2002)." Evelyn Underhill points directly to the biological nature of this need when she says that we have an "innate tendency...towards complete harmony with the transcendental order, whatever the theological formula under which that order is understood" (Underhill, 2002).

Both the need for alignment and the need for connection are arguably biologically rooted. Internal alignment ensures we enhance strengths while external alignment creates the emotional and psychological glue which helps people connect in families and wider groups, both of which facilitate survival, needs satisfaction, and the full development of human potential. It makes survival sense for individuals and individual families to align and connect with the tribe, the community, the town, the grower's organization, etc., because this alignment facilitates inclusion in and attachment to groups, which in turn help individuals fully develop and thrive. A group, a village, for example, can help build homes, produce food, and provide protection for all its 
members. Groups can also help meet other of our needs, like our need for belonging and, in the case of occupational groupings, our need for self-esteem, mastery, or even purpose. Groups can even meet our need for alignment and connection. Religions and spiritual traditions, for example, like Christianity (St. Teresa of Avila, 2007), Sufism (Ernst, 1997), Buddhism (Bodhi, 2005), Zen (Suzuki, 1994), Indigenous spiritualities (Broker, 1983; Lawlor, 1991), and certain spiritually oriented authors, scholars, and elites aim to meet our needs for alignment and connection to our inner self, to our community, to our spiritual guides, to our ancestors, and even to the creator. Authentic traditions always provide ethical, moral, and practical guidance (what we might all alignment/connection guidance) designed to facilitate stronger internal and external connection. Consider Catholic "commandments" like do not covet your neighbours wife, or Buddhist stipulations to Right Livelihood, both of which facilitate attachment, connection, and community health. Maslow captures this normative aspect of alignment and its relationship to connection with his statements about "intrinsic conscience" (Maslow, 1968, p. 7) and his comments on the “bodhisattvic path” (Maslow, 1964).

\section{Decolonizing Attachment_-The Circle of Seven Essential Needs and Eupsychian Attachment Theory}

This brings us to an end of our brief exposition of the Circle of Seven Essential needs and its relationship to AT. The argument is that Bowlby's original theory of attachment was a premature reduction designed to appeal to scientific principles and ideological prejudices rather than being informed by actual empirical reality, all of which may have facilitated translating unacceptable Eurocentric and Capitalist friendly perspectives into acceptability "at the expense of psychological well being" (Carr \& Batlle, 2015, p. 172). Despite the limitations of AT, attachment is obviously important. Thus, the question becomes how to understand attachment without providing a Capitalism friendly, neoliberal reduction. The answer, we feel, is an expanded base, an expanded theory of needs. This is not exactly a revolutionary move. In 2013, Berk, while presenting Bowlby's reductionist model, never the less noted that "By the second half of the first year, infants have become attached to familiar people who have responded to their needs" (Berk, 2013, p. 428). More recently, Harlow (2021) reviews several studies which, 
when combined in their paper, represent a clear, almost Maslovian statement on how healthy parenting is parenting that meets our basic essential needs. It is a very small step from that article to the idea that in order to understand attachment, human pathology, and human development we should spend time better theorizing human needs. The logical place to start, as we have seen, is Maslow; however, limitations require additional theoretical work and a more modern systematization. The Circle of Seven Essential needs overcomes these limitations. It provides a theoretically refined presentation that captures all of Maslow's needs in a culturally neutral and ideologically independent, fashion, offers considerable inspiration for future investigation, and provides an opportunity to break the destructive colonial/European/capitalist agenda embedded in classic AT. It helps us break the agenda in two says.

Number one, it helps us move beyond suppressive Eurocentric models because it is impossible to argue that a single unpaid person can meet all the essential needs identified in The Circle. The only way to actualize full human potential is to move the locus of human health and full development away from a single female, or even a single nuclear family, to a village, a community, and a society that understands humanity's complex constellation of needs and that is consequently geared towards meeting those needs. In this extended view, healthy families, healthy teachers, healthy friend groups, healthy spiritual gurus, and even healthy organizations can form a locus of attachment that can contribute to the health and well-being of the child, adolescent, and adult by helping satisfy essential needs. This move has the added benefit of allowing theorists to re-evaluate collectivist practices, seeing these in a more positive light and perhaps even using them as an inspiration for developing healthier socialization practices less corrupted by a Capitalist agenda.

The second way this theoretical move helps us move beyond Eurocentric models is because it encourages us to ask Maslow's Euspychian Question (Maslow, 1961). The Eupsychian question is basically how do we create a society that can actuate full human potential, develop broader understandings of and support for developing the "ideal, authentic, or perfect godlike human being" (Maslow, 1968, p. 11). Reductive theories like Bowlby's prevent us from asking these questions because of their assumption that Eurocentric socialization systems are superior. 
We already know what we need to do to create disciplined, highly productive workers, so we just need to do that better. However, expanding the needs base brings into stark relief the inadequacy of the European system, a system which arguably sacrifices complete satisfaction of essential needs, particularly our emotional, cognitive, and inner needs, at the alter of Capitalist accumulation. Once we begin to see the inadequacy of the extant European system, we can begin to see our modern Capitalist societies, with their environmentally destructive policies, eating disorders, out of control obesity rates, violence, depression, suicide, homelessness, and despair, as the toxic shit piles they really are. The more we see that, the more we will be drawn to ask the question, "what's the alternative"? The more we ask that question, the more we are drawn to engage with the real problem preventing the human species from finding solutions to the worldending political, economic, ecological, and psychological crises currently unfolding on this planet, which is how to heal the human race from the damage wrought upon them by a system of socialization geared to enriching a few while impoverishing and destroying the many. The answer to that question is complicated but surely an important component is provided by the Circle of Seven Essential Needs underpinning a more sophisticated understanding of attachment. To heal the human and help them move forward, design a socialization process that meets all their essential needs. Doing so will create healthy, happy, competent, intelligent, compassionate, and connected human beings less amenable to manipulation, more likely to connect and develop healthy and supportive communities and as the quote by Vine Deloria suggests, more likely to experience a once-more-common transcendent connection.

Since writing the book, I have been gradually led to believe that the old stories must be taken literally if at all possible, that deep secrets and a deeper awareness of the complexity of our universe was experienced by our ancestors, and that something of their belief, and experiences can be ours once again (Deloria, 2003, p. xvi)

Of course, being as this requires a fundamental revision in norms, values, economic practices, and political orientations, we realize this might sound impossibly Utopian. However, in the ecologically and politically precarious, late-stage capitalist environment we currently find ourselves in, it is not outside the realm of possibility. Global economic productivity is sufficient 
to meet the physiological and environmental needs of all living humans. Guaranteed income plans, which would provide the reduction of work-life necessary to a reorientation of global priorities towards needs satisfaction, could be easily implemented if governments stopped spending so much money on weapons, consumers manipulation, and system maintenance. Finally, a looming survival crises which will only be accelerated if current anti-democratic trends continue, will provide the collective motivation to make the necessary changes. The only thing preventing forward movement at this point is a recalcitrant elite too addicted to money (Sosteric, 2018 b) and power to realize their survival is at stake as well. We feel it is only a matter of time however before they start to clue in as well. Once they do, change will be rapid. It is not a foregone conclusion to be sure, and we feel a regression to a global dark ages is not outside the realm of possibility, but it is within the realm of possibility.

\section{Orienting the Authors}

Mike Sosteric is a white European settler born in Canada and raised by a single-parent, working-class mother. He works as a sociologist and spiritual guide. He grew up on the traditional lands of the Nêhiyawak (Plains Cree), Nahkawininiwak (Saulteaux), Nakota (Assiniboine), Dakota and Lakota (Sioux), and Denesuline (Dene/Chipewyan). Gina Ratkovic is an Indigenous member of the Nakota first nation in Saskatchewan, Canada and also grew up in the Nêhiyawak, Nahkawininiwak, Nakota, and Denesuline nations. She works as a trauma counsellor. As life partners, together they are working to help decolonize sociology, psychology, and therapeutic and spiritual practice. 


\section{References}

Akorede, S. (2018). Three Things To Learn From Google's Workplace Culture. Entrepreneur. https://www.entrepreneur.com/article/317582

Anyon, J. (1980). Social Class and the Hidden Curriculum of Work. Journal of Education, 162(1). https://www.jstor.org/stable/42741976

Aron, A. (1977). Maslow's Other Child. Journal of Humanistic Psychology, 17(2), 9. https://doi.org/10.1177/002216787701700203

Berk, L. E. (2013). Child Development (9th ed.). Pearson.

Bodhi, B. (Ed.). (2005). In the Buddha's Words: An Anthology of Discourses from the Pali Canon. Wisdom Publications.

Bouzenita, A. I., \& Boulanouar, A. W. (2016). Maslow's hierarchy of needs: An Islamic critique. Intellectual Discourse, 24(1). Directory of Open Access Journals.

Bowlby, J. (1944). Forty-four juvenile thieves: Their characters and home-life. International Journal of Psychoanalysis, 25, 19-53. SocINDEX with Full Text.

Bowlby, J. (1966). Maternal care and mental health (14821768; Vol. 3). Schocken Books; PubMed. https://archive.org/details/maternalcarement00bowl/page/n3/mode/2up

Bowlby, J. (1982). Attachment and Loss (Second). Basic Books.

Bridgman, T., Cummings, S., \& Ballard, J. (2019). Who Built Maslow's Pyramid? A History of the Creation of Management Studies' Most Famous Symbol and Its Implications for Management Education. Academy of Management Learning \& Education, 18(1), 81-98. Business Source Complete. https://doi.org/10.5465/amle.2017.0351

Broker, I. (1983). Night Flying Woman: An Ojibway Narrative. Minnesota Historical Society Press. 
Carr, S., \& Batlle, I. C. (2015). Attachment theory, neoliberalism, and social conscience. Journal of Theoretical and Philosophical Psychology, 35(3), 160-176. APA PsycArticles. https://doi.org/10.1037/a0038681

Cassidy, J., Jones, J. D., \& Shaver, P. R. (2013). Contributions of attachment theory and research: A framework for future research, translation, and policy. Development and Psychopathology, 25(4 Pt 2), 1415-1434. PubMed. https://doi.org/10.1017/S0954579413000692

Choate, P. W., CrazyBull, B., Lindstrom, D., \& Lindstrom, G. (2020). Where do we go from here?: Ongoing colonialism from Attachment Theory. Aotearoa New Zealand Social Work, 32(1), 32. Informit Families \& Society Collection. https://doi.org/10.3316/informit.080103162065454

Davis, K. (1957). Human relations in business. McGraw-Hill.

Deloria, V. Jr. (2003). God is Red: A Native View of Religion. Fulcrum Publishing.

Ernst, C. W. (1997). The Shambhala Guide to Sufism. Shambhala Publications.

Everett J. Nelson. (1936). A Note on Parsimony. Philosophy of Science, 3(1), 62-66. JSTOR Journals.

Fanon, F. (1963). The Wretched of the Earth. Grove Press.

Follan M \& Minnis H. (2010). Forty-four juvenile thieves revisited: From bowlby to reactive attachment disorder. Child: Care, Health \& Development, 36(5), 639-645. CINAHL Plus with Full Text. https://doi.org/10.1111/j.1365-2214.2009.01048.x

Frazier, M. L., Gooty, J., Little, L. M., \& Nelson, D. L. (2015). Employee Attachment: Implications for Supervisor Trustworthiness and Trust. Journal of Business and Psychology, 30(2), 373-386. JSTOR Journals. 
Gorz, A. (1999). Reclaiming Work. Pluto.

Harlow, E. (2021). Attachment theory: Developments, debates and recent applications in social work, social care and education. Journal of Social Work Practice, 35(1), 79-91. CINAHL Plus with Full Text. https://doi.org/10.1080/02650533.2019.1700493

Hazan, C., \& Shaver, P. R. (1990). Love and work: An attachment-theoretical perspective. Journal of Personality and Social Psychology, v59(n2). Business Insights Global. https://psycnet.apa.org/doiLanding?doi=10.1037\%2F0022-3514.59.2.270

Hoffman, E. (1999). The Right to be Human: A Biography of Abraham Maslow. McGraw Hill.

Kalisch, I. (2006). Sepher Yezirah: A Book on Creation. The Book Tree.

Kammrath, L. K., \& Clifton, M. (2018). Are you my attachment figure? A (currently) unanswerable question. Social \& Personality Psychology Compass, 12(12), N.PAGN.PAG. Academic Search Complete.

Koltko-Rivera, M. E. (2006). Rediscovering the Later Version of Maslow's Hierarchy of Needs: Self-Transcendence and Opportunities for Theory, Research, and Unification. Review of General Psychology, 10(4), 302-317.

Kuo-Shu Yang. (2003). Beyond Maslow's Culture-Bound Linear Theory: A Preliminary Statement of the Double-Y Model of Basic Human Needs. Nebraska Symposium on Motivation (University of Nebraska Press), 49, 175-255. Supplemental Index.

Lawlor, R. (1991). Voices of the First Day: Awakening in the Aboridinal Dreamtime. Inner Traditions.

Lewis White Beck. (1943). The Principle of Parsimony in Empirical Science. The Journal of Philosophy, 40(23), 617-633. JSTOR Journals. https://doi.org/10.2307/2019692 
Maslow, A. H. (1943a). A Theory of Human Motivation. Psychological Review, 50(4), 370-396. https://doi.org/10.1192/bjp.bp.115.179622

Maslow, A. H. (1943b). Preface to Motivation Theory. Psychosomatic Medicine, 5(1), 85. edb.

Maslow, A. H. (1954). Motivation and Personality. Harper \& Row.

Maslow, A. H. (1961). Eupsychia—The Good Society. Journal of Humanistic Psychology, 1(2), 1.

Maslow, A. H. (1964). Religions, Values, and Peak Experiences. Ohio State University Press.

Maslow, A. H. (1965). Eupsychian management: A journal. Richard D. Irwin Inc. \& The Dorsey Press. https://archive.org/details/eupsychianmanage0000masl/

Maslow, A. H. (1967). A theory of metamotivation: The biological rooting of the value-life. Journal of Humanistic Psychology, 7, 93-127. https://doi.org/10.1177/002216786700700201

Maslow, A. H. (1968). Towards a Psychology of Being (2nd Edition). Van Nostrand Reinhold Company.

Maslow, A. H. (1969). Various Meanings of Transcendence. Journal of Transpersonal Psychology, 1(1), 56-66.

Maslow, A. H. (1970). Motivation and Personality (2nd ed.). Harper \& Row.

McCarthy, J. R., \& Gillies, V. (2018). Troubling Children's Families: Who Is Troubled and Why? Approaches to Inter-Cultural Dialogue. Sociological Research Online, 23(1), 219-244. SocINDEX with Full Text.

McDermid, C. D. (1960). How Money motivates Men. Business Horizons, 3(4), 93-100. ScienceDirect. 
Mercer, J. (2011). Attachment theory and its vicissitudes: Toward an updated theory. Theory \& Psychology, 21(1), 25-45. Complementary Index.

Murphy, S. E., \& Coats, S. (1999). Attachment to groups: Theory and management. Journal of Personality and Social Psychology, 77, 94-110.

Neckoway, R., Brownlee, K., \& Castellan, B. (2007). Is Attachment Theory Consistent with Aboriginal Parenting Realities? First Peoples Child \& Family Review: A Journal on Innovation and Best Practices in Aboriginal Child Welfare Administration, Research, Policy \& Practice, 3(2). Erudit. https://doi.org/10.7202/1069465ar

Nicholson, I. A. M. (2001). "Giving up maleness": Abraham Maslow, masculinity, and the boundaries of psychology. History of Psychology, 4(1), 79-91. APA PsycArticles. https://doi.org/10.1037/1093-4510.4.1.79

Rippeyoung, P. L. F. (2013). Governing Motherhood: Who Pays and Who Profits? Canadian Center for Policy Alternatives. https://www.policyalternatives.ca/sites/default/files/uploads/publications/reports/docs/ Governing\%20Motherhood.pdf

Rosabal-Coto, M., Quinn, N., Keller, H., Vicedo, M., Chaudhary, N., Gottlieb, A., Scheidecker, G., Murray, M., Takada, A., \& Morelli, G. (2017). Real-World Applications of Attachment Theory. In H. Keller \& K. A. Bard (Eds.), Strüngmann Forum Reports (Vol. 22, pp. 335-354). MIT Press. https://doi.org/10.7551/mitpress/9780262036900.003.0014

Rutter, M. (1995). Clinical Implications of Attachment Concepts: Retrospect and Prospect. Journal of Child Psychology \& Psychiatry \& Allied Disciplines, 36(4), 549-571. Academic Search Complete.

Schore, J. R., \& Schore, A. N. (1994). Affect regulation and the origin of the self. Mahweh, NJ. 
Sharon Hays. (1998). The Fallacious Assumptions and Unrealistic Prescriptions of Attachment Theory: A Comment on “Parents' Socioemotional Investment in Children.” Journal of Marriage and Family, 60(3), 782-790. JSTOR Journals. https://doi.org/10.2307/353546

Soper, B., Milford, G. E., \& Rosenthal, G. T. (1995). Belief When Evidence Does Not Support Theory. Psychology and Marketing, 12(5), 415.

Sosteric, M. (2018a). Everybody has a connection experience: Prevalence, confusions, interference, and redefinition. Spirituality Studies, 4(2). https://www.spiritualitystudies.org/dp-volume4-issue2-fall2018/files/assets/common/downloads/files/4-2sosteric.pdf

Sosteric, M. (2018b). How money is destroying the world. The Conversation. https://theconversation.com/how-money-is-destroying-the-world-96517

St. Teresa of Avila. (2007). Interior Castle (Kindle). Dover Publications.

Steeman, T. M. (1975). Church, sect, mysticism, denomination: Periodological aspects of Troeltsch's types. SA. Sociological Analysis, 36(3), 181-204. rfh.

Strazdins, L., \& Broom, D. H. (2004). Acts of Love (and Work): Gender Imbalance in Emotional Work and Women's Psychological Distress. Journal of Family Issues, 25(3), 356-378. https://doi.org/10.1177/0192513X03257413

Suzuki, D. T. (1994). An Introduction to Zen Buddhism. Grove Press.

Townsend, P., \& Wrathall, J. (1997). An Analysis of the Cross-Cujltural Transferability of Western Motivation Theories to the Developing Eastern, China Region [Working Paper].

Underhill, E. (2002). Mysticism: A Study in the Nature and Development of Spiritual Consciousness (Kindle). Dover Publications. 
Voges, J., Berg, A., \& Niehaus, D. J. H. (2019). Revisiting the African origins of attachment research-50 years on from Ainsworth: A descriptive review. Infant Mental Health Journal, 40(6), 799-816. Academic Search Complete.

White, S., Gibson, M., \& Wastell, D. (2019). Child protection and disorganized attachment: A critical commentary. Children and Youth Services Review, 105. ScienceDirect. https://research.birmingham.ac.uk/portal/files/71949158/Child_Protection_and_Disorgan ised_Attachment_revised_SW_MG_2_.pdf

Wren, D. A. (1972). The evolution of management thought. Ronald Press.

Yip, J., Ehrhardt, K., Black, H., \& Walker, D. O. (2018). Attachment theory at work: A review and directions for future research. Journal of Organizational Behavior, 39(2), 185-198. Business Source Complete. 